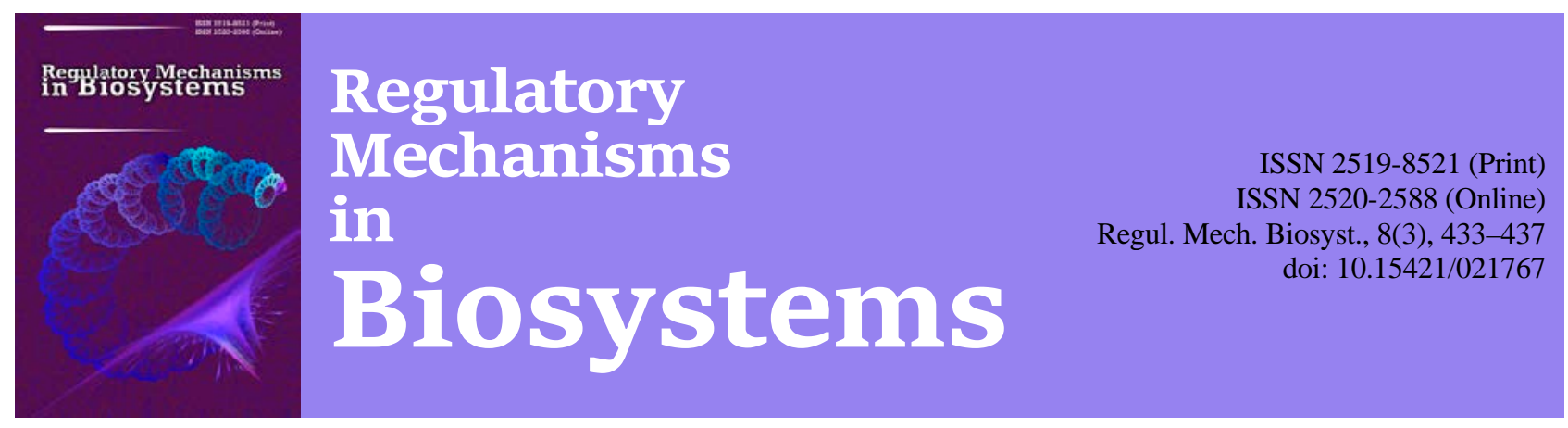

\title{
Dietary energy source affecting fat deposition mechanism, muscle fiber metabolic and overall meat quality
}

\author{
M. Al-Hijazeen, G. Al-Rabadi \\ Mu'tah University, Karak, Jordan
}

\section{Article info}

Received 28.06.2017

Received in revised form 20.07.2017

Accepted 23.07.2017

Mu'tah University, Karak, Mu'tah, 61710, Jordan, P.O. Box(7).

Tel.: 00962-772-665-287.

E-mail: ghaid78@yahoo.com,

alhijazeenmarwan@gmail.com

\begin{abstract}
Al-Hijazeen, M., \& Al-Rabadi, G. (2017). Dietary energy source affecting fat deposition mechanism, muscle fiber metabolic and overall meat quality. Regulatory Mechanisms in Biosystems, 8(3), 433-437. doi: 10.15421/021767
\end{abstract}

\begin{abstract}
A study was conducted to investigate the effect of two dietary energy sources, soy bean oil, and sucrose on regulatory mechanisms of meat preservation. Twenty one day-old Hubbard commercial broilers were randomly allocated into two dietary treatment groups with six replicates per treatment, and four broilers per replicate. All birds were coded for the influence of energy source: fat based diet (FD), and sugar based diet (SD). Formulated grower diets were isonitrogenous and isocaloric. The chickens were slaughtered and then boneless, skinless ground chicken tight meat was prepared. Both raw and cooked meats were analyzed for lipid and protein oxidation, and sensory panel evaluation. In addition, meat from the small muscles of the raw thigh was used to evaluate other meat quality characteristics. Proximate analyses showed no significant differences between both dietary treatments on protein, ash and moisture percentage values. Meat samples of the group that was fed FD showed higher significant values of both TBARS and total carbonyl at day 7 of storage time. However, samples of the second group (Fed SD) showed lower values of both ultimate $\mathrm{pH}$ and water separation \% using raw thigh meat. The effect of FD treatment on the meat composition appeared clearly especially on fat percentage content. In addition, meat samples obtained from chickens fed SD showed better significant values of the overall acceptability attribute. According to the current findings, sucrose could be an excellent alternative to oil in dietary broilers which improved the meat preservation bio-system, and postmortem storage stability.
\end{abstract}

Keywords: poultry; sucrose; thigh meat; lipid oxidation; protein oxidation

\section{Introduction}

Oil is considered the richest energy source among other nutrients (oil contains 2.25 times the energy content of carbohydrate and protein) and thus is used to increase caloric density of diets fed to broilers (Waheed et al., 2004). In addition, oil has been reported to increase the absorption of fat soluble vitamins, increase palatability of the feed and thus feed intake, reduce the passage rate of digesta, which allows higher nutrient absorption (Baiao and Lara, 2005). However, potential hazard is associated in feeding high fat diets if handled incorrectly, one such problem being oil rancidity (Shermer, 1990), this leads to reduction in caloric density of broiler diets. In addition, it may produce off flavours which can reduce broiler feed intake, depress growth, and eliminate the body reservoir of antioxidants (Shermer, 1990; Baiao and Lara, 2005; Tavarez et al., 2011). The harmful influence of oil rancidity brings direct economic losses to broiler farmers and can negatively affect carcass quality (Alao and Balnave, 1984; Zelenka et al., 1997; Crespo and Esteve Garcia, 2002). Therefore, the source of dietary lipid may affect total body fat deposition, fatty acid composition, and overall meat quality (Ellis and Mckeith, 1999; Baiao and Lara, 2005; Fuad and El-Senousey 2014). In addition, it can influence consumer perception, health, and indirectly their food safety (Savell and Cross, 1988). Fatty acid profile and freshness of meat carcass are highly affected and correlated with the fat deposition mechanism. However, the type and degree of polyunsaturated fatty acid is also as important as the total amount of fat deposition in meat, which makes thigh meat more susceptible to lipid per-oxidation compared to other carcass muscles (Min et al., 2008). In addition, cooked meat is more affected by free radicals and oxidized faster than raw meat (Gray et al., 1992; Lee et al., 2003). Thus, initial carcass lipid and protein oxidation level can influence storage stability of chicken meat, especially after thermal processing. Other meat quality characteristics, such as colour, texture, and water holding capacity can also be influenced by the oxidation mechanism and their free radicals formation (Jensen et al., 1997; Du et al., 2000). A sugar (sucrose) has been reported as a better energy source than starch and could be replaced, partially, by fat in poultry diet (Hashim et al., 2013; Hussein et al., 2016). Sucrose is a disaccharide that can be easily digested by poultry (Wang, 2014) and has been reported to have a higher AMEn than glucose (3750 vs. $3330 \mathrm{kcal} / \mathrm{kg}$ ) (Leeson and Summers, 2001). In avian species, glucose has been reported to have a sparing effect on amino acid oxidation (Yadalam, 2005). Furthermore, excess of glucose is stored as glycogen or directed for de novo lipogensis in the liver (Hermier, 1997). In addition, glucose has a higher heat increment compared to lipid. Thus, feeding sucrose may reduce energy delivery to broilers compared to lipid. Reducing energy level in broilers have been reported to decrease total body fat deposition by mechanisms related to decrease in the activity of enzymes linked to hepatic lipogenisis (Tanaka et al., 1983; Fuad and El-Senousey, 2014). Furthermore, change in the dietary energy source will affect the metabolic of muscle fiber type (type I and II), lactic acid accumulation, and postmortem muscle $\mathrm{pH}$ (Aalhus et al., 2009). Lipid in broilers accumulates mainly in the form of polyunsaturated fatty acids (PUFA), which make it more susceptible to oxidative deterioration during storage (Ahn et al., 2002; Min et al., 2008). In modern broiler strains, Choct et al. (2013) reported that broilers contain up to 
$20 \%$ fat and more than $85 \%$ of this fat has no physiological function and thus, reducing fat component in broilers may enhance carcass stability and quality after slaughtering. The aim of current study was to investigate the effect of replacing soy bean oil in broiler grower diet with sucrose on regulatory mechanisms of meat preservation.

\section{Materials and methods}

1. Birds and diet formulation. Forty eight broilers were raised for 21 days (from 21 to 42 days old) according to general commercial husbandry practices. This experiment was reviewed and approved by the Department of Animal Production, and all chickens were checked and their health and welfare cleared by veterinarians. Two groups of 48 broilers were randomly assigned into two dietary treatments (each treatment contains 6 replicates and 4 broilers per replicate). During the experimental period, all birds were raised in floor cages and were offered one of two dietary treatments and water ad lib by using trough feeders and drinkers. The two dietary treatments were formulated to be iso-calroic and iso-nitrogenous. Dietary treatments were coded for the influence of energy source: Fat based diet (FD) and Sugar based diet (SD). The ingredients and chemical composition of experimental diets are shown in Table 1.

\section{Table 1}

Ingredients (\%) and chemical composition (\%) of fat based diet (FD) and Sucrose based diet (SD)

\begin{tabular}{lrr}
\hline \multicolumn{1}{c}{ Ingredients (\%) } & FD & SD \\
\hline Corn & 50.04 & 63.62 \\
Soya bean meal & 27.93 & 16.55 \\
a Broncon concentrate & 10.50 & 11.49 \\
NaCl & 0.19 & 0.19 \\
Limestone & 1.75 & 0.89 \\
bVit. and mineral premix & 0.10 & 0.10 \\
L-Lysine.HCL (78\%) & 0.10 & 3.36 \\
DL-Methioine & 0.23 & 0.40 \\
Degamed soybean oil & 5.27 & 0.00 \\
Monocalcium phosphate & 0.41 & 0.01 \\
Sucrose & 0.00 & 3.30 \\
${ }^{c}$ Antifungi & 0.10 & 0.10 \\
Wheat bran & 3.39 & 0.00 \\
\hline dChemical composition (\%) & & \\
\hline ME, Kcal/kg & 3050 & 3050 \\
Crude protein & 21.00 & 21.00 \\
Crude fibre & 3.93 & 3.10 \\
Ca & 1.30 & 0.90 \\
Non phytate phosphorus & 0.46 & 0.35 \\
Methioine & 0.67 & 0.80 \\
Lysine & 1.25 & 4.25 \\
Cyctein & 0.22 & 0.20 \\
Na & 0.22 & 0.23 \\
Cl & 0.15 & 0.15 \\
\hline
\end{tabular}

Note: ${ }^{\text {a }}$ Brocon Concentrate ${ }^{\circledR}$ (Wafa, B. V., Alblasserdam, Holland); ${ }^{\text {- }}$ - vitamin premix provided per kilogram of premix: Vitamin A, 700,000 IU; vitamin $\mathrm{D}_{3}, 150,000 \mathrm{IU}$; vitamin E, $75 \mathrm{mg}$; vitamin $\mathrm{B}_{1}, 100 \mathrm{mg}$; vitamin $\mathrm{K}, 175 \mathrm{mg}$; vitamin $\mathrm{B}_{5}, 600 \mathrm{mg}$; manganese oxide, $4000 \mathrm{mg}$; ferrous sulphate, $9000 \mathrm{mg}$; zinc oxide, $6000 \mathrm{mg}$; magnesum oxide, $2500 \mathrm{mg}$; potassium iodide, $70 \mathrm{mg}$; sodium selenite, $125 \mathrm{mg}$; copper sulphate, $100 \mathrm{mg}$; cobalt sulphate, $50 \mathrm{mg}$; dicalcium phosphate, $7000 \mathrm{mg}$; sodium chloride, $10000 \mathrm{mg}$; ${ }^{\mathrm{c}}$ - mold inhibitor for animal feed (Kemin Industries, U.S.A); ${ }^{\mathrm{d}}$ - calculated based on analyzed values of feed ingredients (feed composition tables) from poultry NRC (1994).

2. Sample preparation. On day 42, the broilers were slaughtered (Mu'tah University, Agriculture Collage: Department of Animal Production-farm facilities) using standard guidelines of poultry slaughterring in Jordan (Ministry of Agriculture) and under the supervision of veterinarians. The chicken carcasses were chilled in ice water for $2 \mathrm{~h}$ and drained in a laboratory cold room, and the muscles (thigh meat) were separated from the carcasses at $24 \mathrm{~h}$ after slaughtering. Boneless thigh muscles were cleaned, skins removed, external fats trimmed off, vacuum packaged in oxygen impermeable bags, and stored at $-18^{\circ} \mathrm{C}$ in a freezer until used for further analysis. Thigh meat was selected for this study analysis because of its high fat content and myoglobin pigment, and its mixture of muscle fiber (different metabolic) type.
Separated raw meat samples were stored for 7 days at $4{ }^{\circ} \mathrm{C}$ and were used to evaluate meat quality characteristics. Different parameters were measured to evaluate the effect of dietary energy source on muscle fiber metabolic, fat deposition mechanisms indirectly; and on meat preservation. For stability analysis (lipid and protein oxidation) frozen meats were thawed in a walk-in cooler $\left(4^{\circ} \mathrm{C}\right)$, ground twice through 8 and a $3 \mathrm{~mm}$ plates (Moulinex, Type DKA1, France), respectively, before use. Meats of each treatment replicate $(n=6)$ were ground and homogenated as a single batch, and subdivided into $50 \mathrm{~g}$ of ground meat patties. The prepared raw meat patties were packaged in oxygen permeable bags (Size: $11 \times 25 \mathrm{~cm}$, Future for Plastic Industry, Al-Moumtaz bags, Co. LTD, Jordan) in a cold room at $4{ }^{\circ} \mathrm{C}$ for up to 7 days for quality analysis. In the study related cooked-patties, the raw meat was placed in oxygen impermeable vacuum plastic-bags (Ehsan \& Tahssin Baalbaki Co, Bayader Wadi Al-Seer, Amman, Jordan), then cooked in-bag in a $90^{\circ} \mathrm{C}$ water bath (Memmert, WNB 14; GMbH + Co. KH, D-91107 Schwabach, Germany). Samples were moved out when the internal temperature of the meat patties was $75^{\circ} \mathrm{C}$. After cooling, the cooked meat patties (50 g) was placed inside new oxygen-permeable bags, stored at $4{ }^{\circ} \mathrm{C}$, and analyzed for lipid (TBARS) and protein oxidation at three time intervals. Same preparation procedure was done for all sensory analysis treatment samples. However, the ground chicken (raw thigh) meat patties were stored at $4{ }^{\circ} \mathrm{C}$ up to 4 days before cooking, and for each evaluation session.

3. Thiobarbituric acid-reactive substances (TBARS) measurement. Briefly, the TBARS values in the meat samples were measured according to the method described by Ahn et al. (1998). The TBARS values were calculated based on malonaldehyde (MDA) stander carve (TEP standard solution) and reported as mg of MDA per kg of meat.

4. Protein oxidation (total carbonyl). Protein oxidation was determined by the method of Lund et al. (2008) with minor modifycations as described by Al-Hijazeen et al. (2016). In addition, carbonyl content was recorded as $\mathrm{nmol} / \mathrm{mg}$ protein using absorption coefficient of 22,000/M.cm as described by Levine et al. (1994).

5. Proximate analysis. Proximate analysis was determined for all treatment samples according to the method of AOAC (2003). Moisture, crude protein, fat and ash (\%) were analyzed using thigh meat samples. Samples of each treatment were selected randomly and the averages of 6 sub-samples (2 sample/replicate) were statistically analyzed.

6. pH of raw thigh meat. Acidity of the chicken raw meat samples was measured using a $\mathrm{pH}$ meter (PL-600, $\mathrm{pH} / \mathrm{mV} /$ Temp Meter, Taiwan) after homogenizing the $1.0 \mathrm{~g}$ samples with $9 \mathrm{ml}$ deionzed distilled water (DDW) (Sebranek et al., 2001).

7. Cooking loss \%. Chicken thigh meat samples (30 g) were weighed and packaged in oxygen impermeable vacuum bags. The meat was cooked at a constant temperature using pre-heated water bath (Memmert, WNB 14; GMbH + Co. KH, D-91107 Schwabach, Germany) to the internal temperature of $80^{\circ} \mathrm{C}$ for $90 \mathrm{~min}$ for the maximum water loss expected (Murphy and Marks, 2000). After cooking, all meat samples were cooled in a cold water bath until the internal temperature of the samples reached $20^{\circ} \mathrm{C}$, then water blotted or purged until the samples became dry. The cooking loss percentage was calculated as percent weight reduction of the cooked sample compared to the raw meat sample using the following equation:

\section{Cooking loss $\%=\underline{100 \times \text { (Weight of raw meat }- \text { Weight of cooked meat) }}$} (Weight of raw meat)

8. Water separation (Centrifuge method). Samples of $20 \mathrm{~g}$ (meat/ water mixture) were placed into $50 \mathrm{~mL}$ centrifuged tubes to measure their separated water as described by Sebranek et al. (2001) with minor modification. The samples were placed in tubes then centrifuged at the speed of 10,000 rpm for 20 minutes (High Speed Centerfuige, TG16G, Hunan Kaida, China). After centrifugation, the excess water was decanted and tubes were re-weighed. Water separation percentage (expression of water holding ability) was calculated as ratio of centrifuged water to the original sample weight. This method measures how strongly water is bound or held by meat proteins.

9. Sensory evaluation. Trained sensory panels were used to evaluate the sensory characteristics of the ground chicken thigh meat. 
Sensory panels evaluated the colour, aroma, and overall acceptability of both raw and cooked meat. Two different treatments were prepared with the same method described in the oxidation analysis (lipid and protein oxidation). The meat was refrigerated at $4{ }^{\circ} \mathrm{C}$ for three days before each evaluation session. Ten trained panelists (Muta'h University, students and staff), participated in each session. The evaluations were done twice after three days of storage time at $4{ }^{\circ} \mathrm{C}$. For training, 3 one-hour sessions were held using commercial ground chicken meat to develop descriptive terms for the desired attributes. The raw meat was evaluated for colour (redness), visual fat, oxidative odour, and overall acceptability. On the other hand, cooked meats were evaluated for cooked chicken odor, oxidative odour, sulfur odour, and overall acceptability.

All attributes were measured using a line scale without numbers (numerical value 9 units) with graduation from 0 to 9 . For example, overall acceptability; where 9 represented extremely desirable, and 0 represented extremely undesirable ( 9 - extremely desirable, 8 - very, 7 moderate, 6 - slightly, 5 - neither nor, 4 - slightly undesirable, 3 - moderately undesirable, 2 - very undesirable, and 1 - extremely undesirable). Similar terminology (e.g detectable or undetectable) underline was used for the other attributes. Cooked and raw meat evaluation sessions were done on separate days to decrease any variability.

Refrigerated $\left(4^{\circ} \mathrm{C}\right)$ samples were evaluated by the panelists for each treatment. The panelist was served 1 glass vial, $20 \mathrm{ml}$ volume, of each treatment to evaluate colour and odor of raw thigh meat. All ground meat samples were packaged in oxygen permeable bags before the evaluation session. The panelists were asked to evaluate the ground meat patties (color) and open the vials to evaluate odour. The raw meat samples of $10 \mathrm{~g}$ each were placed in small vials $(20 \mathrm{~mL})$ capped with a septum in order to evaluate odor attributes. All sample vials were labeled by a three digit number selected randomly. For cooked meat, samples ( $4 \mathrm{~g})$ at 0 day of cooking were placed in a three digit coded $20 \mathrm{~mL}$ sample vial and capped with a septum. Panelists were asked to smell samples in random order and record the intensity of odor or overall acceptability on the scale line.

10. Statistical analysis. Data were analyzed using statistical analysis of SAS program, version 9.3 (2012). For all analysis, the student $t$ test at $5 \%$ level of significance was used to compare the measured means between the two treatments. Mean values and standard deviation of the means (Mean \pm SD) were reported.

\section{Results and discussion}

Proximate analysis. In order to evaluate the effect of adding different dietary energy sources on the meat preservation system, it is important to analyze meat composition. There were no significant differences $(P>0.05)$ between both treatments of their moisture, protein, and ash percentage (Table 2). However, the moisture values were numerically lower using FD treatment samples. This may be due to higher $(\mathrm{P}<0.05)$ value of fat in their lean meat tissues (Table 2$)$.

Table 2

Proximate analysis of raw chicken thigh meat (Mean \pm SD, $n=6$ )

\begin{tabular}{lcccc}
\hline Treatment & Fat \% & Protein \% & Ash \% & Moisture \% \\
\hline FD & $7.23 \pm 0.10$ & $21.4 \pm 0.76$ & $0.98 \pm 0.017$ & $70.4 \pm 0.82$ \\
SD & $6.23 \pm 0.27$ & $21.6 \pm 0.99$ & $0.98 \pm 0.017$ & $71.2 \pm 1.14$ \\
P-value & $<0.0001$ & 0.7993 & 1.0000 & 0.1613 \\
\hline
\end{tabular}

Although both dietary treatments were formulated to be isocalric and isonitrogenous, Glucose/sugar has a higher heat increment compared to lipid after metabolism (De Groote et al., 1971). Thus, feeding sucrose may reduce net energy delivery to the broilers compared to lipid. Reducing energy level in broilers has the result of decreasing total body fat deposition (Tanaka et al., 1983). Furthermore, broilers fed SD had a lower feed intake (Data were not shown). Lower feed intake through feed restriction has been reported to decreased energy delivery and thus body fat accumulation (Rezaei et al., 2010; Chen et al., 2012; Wu et al., 2012). This significant difference in fat meat should be the major factor which can affect meat quality and their stability during storage time. However, low fat content may affect negatively some eating quality characteristics (tenderness, juiciness, odor, and flavor) and consumer acceptance (Savell and Cross, 1988; Ellis and Mckeith, 1999).

Lipid oxidation. There were no significant differences $(\mathrm{P}>0.05)$ between TBARS values (raw and cooked thigh meat) of both FD and SD treatment at day 0 (Table 3).

\section{Table 3}

TBARS* values (mg/kg) of ground chicken thigh meat at different storage time (Mean $\pm \mathrm{SD} ; \mathrm{n}=6$ )

\begin{tabular}{lccr}
\hline Time & FD & SD & \multicolumn{1}{c}{ P-value } \\
\hline & \multicolumn{3}{c}{ Raw } \\
Day 0 & $0.232 \pm 0.029$ & $0.247 \pm 0.047$ & 0.5408 \\
Day 4 & $0.968 \pm 0.069$ & $0.289 \pm 0.028$ & $<0.0001$ \\
Day 7 & $2.495 \pm 0.042$ & $1.244 \pm 0.015$ & $<0.0001$ \\
\hline & \multicolumn{3}{c}{ Cooked } \\
Day 0 & $1.207 \pm 0.510$ & $1.064 \pm 0.143$ & 0.5350 \\
Day 4 & $3.537 \pm 0.182$ & $1.832 \pm 0.652$ & 0.0010 \\
Day 7 & $7.416 \pm 0.234$ & $5.198 \pm 0.869$ & 0.0011 \\
\hline
\end{tabular}

Note: * - TBARS value in mg malonaldehyde/kg meat.

This was in agreement with the previous research studies conducted on ground chicken meat (Rababah et al., 2006; Chouliara et al., 2007; Al-Hijazeen et al., 2016). In addition, TBARS values of raw meat samples obtained from FD treatment were significantly $(\mathrm{P}<$ 0.05 ) higher at day 4 of storage time. Furthermore, TBARS values of FD treatment were significantly $(\mathrm{P}<0.05)$ lower using raw meat at day 7 of storage time. This may be due to the higher fat content and fatty acid profile in meat samples of broilers that were fed FD. However, initiation and propagation steps (autoxidation reaction) in lipid oxidation mechanism are highly affected by fatty acid saturation and their profile sequences (Ahn et al., 2009). In addition, the TBARS values using cooked meat were significantly $(\mathrm{P}<0.05)$ higher for FD treatment compared to SD treatment. Generally, the TBARS values in cooked chicken meat were higher than raw meat, and the signifycances could be better if cooked meat was used (Min et al., 2008; Ahn et al., 2009). This may be due to the low free iron content and high ferric ion reducing capacity in fresh meat (Min et al., 2008). In addition, the oxidative change is usually higher in cooked meat because enzymes denatured, iron ion released to the extracellular compartment, membrane bi-layers damaged, and phospholipids were oxidized faster during cooking (Gray et al., 1996). So the TBARS values of SD treatment increased during storage time with a lower rate compared to the FD treatment. However, farther research studies are needed to investigate the mechanism of fatty acid deposition using different dietary energy.

Protein oxidation. There were no significant differences $(\mathrm{P}>$ 0.05 ) of the total carbonyl (nmol/mg protein) values using both dietary treatments at day 0 . However, these values of FD treatment were significantly higher $(\mathrm{P}<0.05)$ at days 4 and 7 of storage time using both raw and cooked meat (Table 4).

\section{Table 4}

Effect of using different dietary energy sources on protein oxidation in ground chicken meat at different storage time (carbonyl, $\mathrm{nmol} / \mathrm{mg}$ of protein; Mean $\pm \mathrm{SD}, \mathrm{n}=6$ )

\begin{tabular}{cccc}
\hline Time & FD & SD & P-value \\
\hline & \multicolumn{3}{c}{ Raw } \\
Day 0 & $0.785 \pm 0.140$ & $0.761 \pm 0.063$ & 0.712 \\
Day 4 & $1.429 \pm 0.049$ & $0.953 \pm 0.078$ & $<0.0001$ \\
Day 7 & $1.711 \pm 0.463$ & $1.168 \pm 0.061$ & 0.0343 \\
\hline \multicolumn{3}{c}{ Cooked } \\
Day 0 & $1.398 \pm 0.099$ & $1.384 \pm 0.132$ & 0.8424 \\
Day 4 & $2.712 \pm 0.364$ & $2.167 \pm 0.108$ & 0.0131 \\
Day 7 & $4.334 \pm 0.304$ & $2.629 \pm 0.252$ & $<0.0001$ \\
\hline
\end{tabular}

This may be due to free radical formation, which accelerates during storage time (Estevez, 2011). Sugar based diet (SD) treatment showed a lower increasing rate during storage time of the raw meat samples. Furthermore, total carbonyl values in cooked meat were much higher than those of raw meat and reached up to $4 \mathrm{nmol} / \mathrm{mg}$ 
protein by the end of storage time (Table 4). Total estimated carbonyl values were reported in the range of $1-3 \mathrm{nmol} / \mathrm{mg}$ protein for raw meat and up to $5 \mathrm{nmol} / \mathrm{mg}$ protein for cooked meat (Estevez et al., 2005; Sun et al., 2010; Estevez, 2011). This increasing trend of total carbonyl formation was connected to the TBARS or MDA changing the rate of the SD treatment. Certainly, the interaction between both lipid and protein oxidation support this explanation (Xiong, 2000).

These results were in agreement with the findings of Al-Hijazeen et al. (2016), where the TBARS values in both raw and cooked ground chicken meat increased during storage. In addition, the effect of using different levels of essential amino acids with high energy poultry diet has been reported to affect their carcass quality (Moran and Bilgili, 1990; Ellis and Mckeith, 1999; Aletor et al., 2000). In addition, the suitable protein usage in all feeding systems is important economically and nutritionally (Beski et al., 2015). Finally, these results reflect the effect of changes in energy metabolism, nutrient absorption, and amino acid profile due to dietary energy sources (Krajmalnik-Brown et al., 2012).

Meat quality parameters. Water binding ability is considered important in meat quality and its processing characteristics. However, it will affect other eating quality characteristics such as juiciness, texture; flavour and meat marketing benefit (Huff-Lonergan et al., 2005; Cheng and Sun, 2008). In addition to the water binding ability, cooking loss and ultimate $\mathrm{pH}$ value of thigh meat samples were measured. Data analysis of the current study showed no significant differences $(\mathrm{P}>0.05)$ between both treatments values of cooking loss (Table 5).

\section{Table 5}

Effect of dietary treatment on meat quality characteristics (cooking loss, water separation), and $\mathrm{pH}$ value of thigh chicken meat (Mean $\pm S D, n=6$ )

\begin{tabular}{lccc}
\hline \multicolumn{1}{c}{ Parameter } & FD & SD & P-value \\
\hline${ }^{1}$ Cook L & $0.201 \pm 0.017$ & $0.166 \pm 0.043$ & 0.088 \\
${ }^{2}$ WS & $0.257 \pm 0.020$ & $0.211 \pm 0.024$ & 0.016 \\
${ }^{3} \mathrm{pH}$ value & $6.240 \pm 0.179$ & $5.713 \pm 0.262$ & 0.002 \\
\hline
\end{tabular}

Note: ${ }^{1}$ - Cook L - cooking loss percentage; ${ }^{2}$ - WS - water separation percentage; ${ }^{3}-\mathrm{pH}$ - ultimate $\mathrm{pH}$ value at day 0 .

On the other hand, ultimate $\mathrm{pH}$ values of meat samples from SD treatment were significantly lower $(\mathrm{P}<0.05)$ compared to FD treatment. This effect may be due to glycogen (multi-branched polysaccharide of glucose) stored in the muscle cells, which may affect final $\mathrm{pH}$ value in the meat after slaughtering (Den HertogMeischke et al., 1997). However, the effect of dietary energy sources on early postmortem muscle metabolism (Glycolytic enzyme) had been reported in several studies (Greenhaff et al., 1988; Li et al., 2017). In addition, treatment samples of FD showed higher significant values of water separation compared to the SD treatment. Despite the lower $\mathrm{pH}$ value in the sample of SD, it showed better water binding ability. The reason for this may be due to the effect of fat composition, and the negative effect of lipid oxidation on meat protein. Finally, water holding capacity of raw meat is complicated by many internal and external factors (Huff-Lonergan et al., 2005), for example, physiological, rearing conditions and factors with regard to slaughter and farther processing (Den Hertog-Meischke et al., 1997).

Sensory analysis. Different sensory attributes were evaluated reflecting the relationship between regulator mechanism of meat preservation (pre-postmortem time) and overall meat quality. The evaluation panel of the cooked samples showed no significant differences $(\mathrm{P}>0.05)$ between both treatments (FD and SD) using colour and sulfur odour attributes. However, this significant difference could be clearer if the meat samples were evaluated by chemical or instrumenttal analysis. In addition, FD treatment showed higher significant $(\mathrm{P}<$ 0.05 ) scores of the oxidation odour attribute compared to SD (Table 6).

Fatty acids profile and high fat composition of FD samples in muscle tissues may be the reason behind this variation among these attributes (Ellis and Mckeith, 1999; Ahn et al., 2009). In addition, changes in dietary energy source may affect gut microbes, and the mechanism of nutrient absorption (Krajmalnik-Brown et al., 2012). Overall, cooked meat samples from SD treatment were significantly $(\mathrm{P}<0.05)$ more acceptable compared to the FD samples (overall acceptability). This could be explained by the differences in fatty acid profile and their amino acid composition (Melton, 1990). These differences usually affect odour, flavour, colour, and other meat quality characteristics, and correlated with lipid and protein oxidation (Min et al., 2008; Ahn et al., 2009).

\section{Table 6}

Sensory attributes ${ }^{\mathrm{b}}$ means

of ground chicken thigh meat patties (Mean \pm SD)

\begin{tabular}{ccccc}
\hline \multirow{2}{*}{ TRT* } & Cooked & Sulfur & Oxidation & Over All \\
\cline { 2 - 5 } & Colour & Odour & Odour & Acceptability \\
\hline \multirow{3}{*}{ Fat Diet } & $5.74 \pm 1.87$ & Cooked & \\
Sugar Diet & $7.28 \pm 1.33$ & $7.18 \pm 0.74$ & $5.87 \pm 1.31$ \\
P-value & 0.0688 & 0.5400 & $<0.0001$ & 0.0006 \\
\hline \multirow{2}{*}{ TRT $*$} & Redness & Visual & Oxidation & Over All \\
\cline { 2 - 5 } & Colour & Fat & Odour & Acceptability \\
\hline \multirow{5}{*}{ Fat Diet } & $5.74 \pm 1.45$ & $5.83 \pm 0.81$ & $5.73 \pm 0.43$ & $4.38 \pm 0.93$ \\
Sugar Diet & $7.13 \pm 1.02$ & $2.87 \pm 0.48$ & $3.28 \pm 0.59$ & $7.75 \pm 0.87$ \\
P-value & 0.0233 & $<0.0001$ & $<0.0001$ & $<0.0001$ \\
\hline
\end{tabular}

Note: * - treatments - fat diet, sugar diet; ${ }^{\mathrm{b}}$ - sensory attributes - samples of cooked and raw meat were evaluated at day 0 and 3 respectively $(n=10)$.

Raw meat samples of SD treatment showed higher significant $(\mathrm{P}>0.05)$ scores using redness attribute compared to FD treatment. In addition it showed better cooked meat colour scores compared to the FD treatment. Clearly, FD treatment showed higher significant $(P>0.05)$ scores of visual fat attribute. This may be due to the higher fat accumulation in the muscle tissues of broilers that were fed with soy bean oil. Similar to the cooking evaluation, FD treatment samples had significantly $(\mathrm{P}<0.05)$ higher scores of oxidation odour using raw meat samples. In addition, SD treatment showed higher significant $(\mathrm{P}<0.05)$ scores of the overall acceptability attribute.

\section{Conclusion}

The SD treatment showed the lowest significant $(\mathrm{P}<0.05)$ lipid and protein oxidation values compared to the other treatment. In addition, FD treatment showed higher significant water separation of raw thigh meat samples. Results of the sensory evaluation were in agreement with the previous chemical analysis data. It can be concluded that SD treatment could be a good replacement to the FD in term of meat storage stability if used in a suitable level. However, more research studies are needed to ascertain all meat quality characteristics. Finally, this regulatory bio-system approach should have a promising future in poultry production and meat preservation. In addition, it will enhance food safety, decrease carcinogenic and toxicological effects of free radicals, and improve human health.

This study was financially supported by the Deanship of Scientific Research at Mu'tah University, Al-Karak, Jordan. This funding is highly appreciated. We also convey our profound gratitude to all other Animal Science Department staff for their help and expert advice.

\section{References}

Ahn, D. U., \& Lee, E. J. (2002). Production of off-odor volatiles from liposomecontaining amino acid homopolymers by irradiation. Journal of Food Science, 67(7), 2659-2665.

Ahn, D. U., Nam, K. C., \& Lee, E. J. (2009). Lipid oxidation and flavor. In: Du, M., \& McCormick, R. J. (Eds.). Applied muscle biology and meat science. CRC Press, Taylor and Francis Group, Baco Raton, FL. Cap 12, pp. 227-246.

Ahn, D. U., Olson, D. G., Jo, C., Chen, X., Wu, C., \& Lee, J. I. (1998). Effect of muscle type, packaging, and irradiation on lipid oxidation, volatile production and color in raw pork patties. Meat Science, 49, 27-39.

Alao, S. J., \& Balnave, D. (1984). Growth and carcass composition of broiler fed sunflower and olive oil. British Poultry Science, 25, 209-219. 
Aletor, V. A., Hamid, I. I., Nieb, E., \& Pfeffer, E. (2000). Low-protein amino acid-supplemented diets in broiler chickens: Effects on performance, carcass characteristics, whole-body composition and efficiencies of nutrient utilization. Journal of the Science of Food and Agriculture, 80(5), 547-554.

Al-Hijazeen, M., Lee, E. J., Mendonca, A., \& Ahn, D. U. (2016). Effect of oregano essential oil (Origanum vulgare subsp. hirtum) on the storage stability and quality parameters of ground chicken breast meat. Antioxidant (MDPI), 5, 18.

AOAC (2003). Official methods of Analysis (17th ed., 2nd revision). Association of Official Analytical Chemists, Virginia, USA.

Baiao, N. C., \& Lara, L. J. C. (2005). Oil and fat in broiler nutrition. Brazilian Journal of Poultry Science, 7, 129-141.

Beski, S. S. M., Swick, R. A., \& Lji, P. A. (2015). Specialized protein products in broiler chicken nutrition: A review. Animal Nutrition, 1(2), 47-53.

Chen, W., Guo, Y. M., Huang, Y. Q., Shi, Y. H., Zhang, C. X., \& Wang, J. W. (2012). Effect of energy restriction on growth, slaughter performance, serum biochemical parameters and Lpin2/WDTC1 mRNA expression of broiler in the later phase. Journal of Poultry Science, 49, 12-19.

Cheng, Q., \& Sun, D. W. (2008). Factors affecting the water holding capacity of red meat products: A review of recent research advances. Critical Reviews in Food Science and Nutrition, 48(2), 137-159.

Chouliara, E., Karatapanis, A., Savvaidis, I. N., \& Kontominas, M. G. (2007). Combined effect of oregano essential oil and modified atmosphere packaging on shelf-life extension of fresh chicken breast meat, stored at $4 \mathrm{C}$. Food Microbiology, 24, 607-617.

Crespo, N., \& Esteve-Garcia, E. (2002). Nutrient and fatty acid deposition in broilers fed different fatty acid profiles. Poultry Science, 81, 1533-1542.

De Groote, G., Reyntens, N., \& Amich-Gali, J. (1971). Fat studies. The metabolic efficiency of energy utilization of glucose, soybean oil and different animal fats by growing chickens. Poultry Science, 50, 808-818.

Den Hertog-Meischke, M. J. A., Van Laack, R. J. L. M., \& Smulders, F. J. M. (1997). The water-holding capacity of fresh meat. Veterinary Quarterly, 19(4), 175-181.

Du, M., \& Ahn, D. U. (2002). Effect of antioxidant on the quality of irradiated sausages prepared with Turkey thigh meat. Poultry Science, 81, 1251-1256.

Du, M., Ahn, D. U., Nam, K. C., \& Sell, J. L. (2000). Influence of dietary conjugated linoleic acid on the volatile, color and lipid oxidation of irradiated raw chicken meat. Meat Science, 56, 387-395.

Ellis, M., \& Mckeith, F. K. (1999). Effect of nutrition on meat quality. Non-ruminant nutrition and meat quality. 2nd Annual Reciprocal Meat Conference, 52, 15-23.

Estevez, M. (2011). Protein carbonyls in meat system: A review. Meat Science, 89, 259-279.

Estevez, M., Ventanas, S., \& Cava, R. (2005). Protein oxidation in frankfurters with increasing levels of added rosemary essential oil: Effect on color and texture deterioration. Journal of Food Science, 70, 427-432.

Fouad, A. M., \& El-Senousey, H. K. (2014). Nutritional factors affecting abdominal fat deposition in poultry: A Review. Asian-Australasian Journal of Animal Sciences, 27(7), 1057-1068.

Gray, J. I., \& Monahan, F. J. (1992). Measurement of lipid oxidation in meat and meat products. Trend in Food Science and Technology, 3, 315-319.

Gray, J. I., Gomaa, E. A., \& Buckley, D. J. (1996). Oxidative quality and shelf life of meats. Meat Science, 43, 111-123.

Greenhaff, P. L., Gleeson, M., \& Maughan, R. J. (1988). The effect of diet on muscle $\mathrm{pH}$ and metabolism during high intensity exercise. European Journal of Applied Physiology and Occupational Physiology, 57(5), 531-539.

Hall, G. (1987). Interactions between products of lipid oxidation and proteins. Food Science and Technology Today, 1, 155-158.

Hashim, I. B., Hussein, A. S., \& Afifi, H. S. (2013). Quality of breast and thigh meats when broilers are fed rations containing graded levels of sugar syrup. Poultry Science, 92(8), 2195-2200.

Hermier, D. (1997). Lipoprotein metabolism and fattening in poultry. Journal of Nutrition, 127, 805-808.

Huff-Lonergan, E., \& Lonergan, S. M. (2005). Mechanisms of water-holding capacity of meat: The role of postmortem biochemical and structural changes. Meat Science, 71(1), 194-204.

Hussein, A. S., Al Ghurair, J., John, P. G. K., Habib, H. M., \& Sulaiman, M. (2016). Graded levels of sugar syrup in broiler rations and its effect on growth performance and blood biochemical parameters. Animal Nutrition, 2, 180-185.

Jensen, C., Guidera, J., Skovgaard, I. M., Staun, H., Skibstead, L. H., Jensen, S. K., Moller, A. J., Bukley, J., \& Bertelsen, G. (1997). Effect of dietary $\alpha$-tocophe- rol deposition in porcine $m$. psoas major and $m$. longissimus dorsi and on drip loss, colour stability of pork meat. Meat Science, 45(4), 491-500.

Krajmalnik-Brown, R., Iihan, Z., Kang, D., \& Dibaise, J. K. (2012). Effect of gut microbes on nutrient absorption and energy regulation. Nutrition in Clinical Practice, 27(2), 201-214.

Lee, K., Everts, H., Kappert, H., Yeom, K., \& Beynen, C. (2003). Dietary carvacrol lowers body weight gain but improves feed conversion in female broiler chickens. Journal of Applied Poultry Research, 12, 394-399.

Leeson, S., \& Summers, J. D. (2001). Nutrition of the chicken. 4th edition. M. L. Scott and Associates, Ithaca, N.Y.

Levine, R. L., Williams, J. A., Stadtman, E. R., \& Shacter, E. (1994). Methods in Enzymology, 233, 346-357.

Li, Y., Yu, C., Li, J., Zhang, L., Gao, F., \& Zhou, G. (2017). Effect of dietary energy sources on early postmortem muscle metabolism of finishing pigs. Asian-Australians Journal of Animal Science, in press.

Lund, M. N., Hviid, M. S., Claudi-Magnussen, C., \& Skibsted, L. H. (2008). Effects of dietary soybean oil on lipid and protein oxidation in pork patties during chill storage. Meat Science, 79, 727-733.

Melton, S. L. (1990). Effect of feed on flavor of red meat: A review. Journal of Animal Science, 68(12), 4421-4435.

Min, B. R., Nam, K. C., Cordray, J. C., \& Ahn, D. U. (2008). Factors affecting oxidative stability of pork, beef, and chicken meat. Animal Industry Report, AS654, ASL R2257.

Moran, E. T., \& Bilgili, S. F. (1990). Processing losses, carcass quality, and meat yields of broiler chickens receiving diets marginally deficient to adequate in lysine prior to marketing. Poultry Science, 69(4), 702-710.

Murphy, R. Y., \& Marks, B. P. (2000). Effect of meat temperature on proteins, texture and cook loss for ground chicken breast patties. Poultry Science, 79, 99-104.

Rababah, T., Hettiarachchy, N. S., Horax, R., Cho, M. J., Davis, B., \& Dicksons, J. (2006). Thiobarbituric acid reactive substances and volatile compounds in chicken breast meat infused with plant extracts and subjected to electron beam irradiation. Poultry Science, 85, 1107-1113.

Rezaei, M., \& Hajati, H. (2010). Effect of diet dilution at early age on performance, carcass characteristics and blood parameters of broiler chicks. Italian Journal of Animal Science, 9, 93-100.

Savell, J. W., \& Cross, H. R. (1988). Technological option to improve the nutritional attributes of animal product options in the marketplace. Washington (DC): National Academic Press (US). The role of fat in the palatability of beef, pork, and lamb. pp. 1-94.

Sebranek, J. G., Lonergan, S. M., King-Brink, M., \& Larson, E. (2001). Meat science and processing. Lab-Manual. 3rd ed. Zenda, WI, Peerage Press. pp. 141-143.

Shermer, W. D. (1990). Effects of oxidation on the quality of ingredients and feed of poultry. In: $37^{\circ}$ Maryland Nutrition Conference. Maryland, EUA.

Sun, W. Q., Zhang, Y. J., Zhou, G. H., Xu, X. L., \& Peng, Z. Q. (2010). Effect of apple polyphenol on oxidative stability of sliced cooked cured beef and pork hams during chilled storage. Journal of Muscle Food, 21, 722-737.

Tanaka, K., Ohyani, S., \& Shigeno, K. (1983). Effect of increasing dietary energy on hepatic lipogenesis in growing chicks. II. Increasing energy by fat or protein supplementation. Poultry Science, 62, 452-458.

Tavarez, M. A., Boler, D. D., Bess, K. N., Zhao, J., Yan, F., Dilger, A. C., McKeith, F. K., \& Killefer, J. (2011). Effect of antioxidant inclusion and oil quality on broiler performance, meat quality, and lipid oxidation. Poultry Science, 90(4), 922-930.

Waheed, A., Ahmed, T., Yousaf, A., \& Zaefer, I. J. (2004). Effect of various levels of fat and antioxidant on the quality of broiler rations stored at high temperature for different periods. Pakistan Veterinary Journal, 24(2), 70-75.

Wang, A. (2014). The effects of different feeding program and inclusion of glycerol, glucose or sucrose in broiler starter diets on growth performance and intestinal development. Master thesis. Dalhousie University, Halifax, Canada.

Wu, L., Guo, X., \& Fang, Y. (2012). Effect of diet dilution ratio at early age on growth performance, carcass characteristics and hepatic lipogensis of Pekin ducks. Brazilian Journal of Poultry Science, 14, 43-49.

Xiong, Y. L. (2000). Protein oxidation and implications for muscle food quality. In: Decker, E. A., Faustman, C., \& Lopez-Bote, C. J. (Eds.), Antioxidants in muscle foods. Wiley, New Yourk. pp. 85-111.

Yadalam, S. (2005). Modeling broiler energy and protein metabolism. $\mathrm{PhD}$ thesis. Faculty of the Graduate College, Oklahoma State University, USA.

Zelenka, W., Knaus, W., Aichinger, F., \& Lettner, F. (1997). Effects of different dietary fat sources on performance and carcass characteristics of broilers. Animal Feed Science and Technology, 66, 63-73. 